\title{
Laimaphelenchus suberensis sp. nov. associated with Quercus suber in Portugal
}

\author{
Carla Maria Nobre Maleita $\cdot$ Sofia R. Costa • \\ Isabel Abrantes
}

Accepted: 16 August 2017 /Published online: 31 August 2017

C) Koninklijke Nederlandse Planteziektenkundige Vereniging 2017

\begin{abstract}
Laimaphelenchus suberensis sp. nov. obtained from declining Quercus suber trees of Herdade da Gouveia de Baixo, Alentejo, Portugal, is described and illustrated based on morphological, biometrical and molecular characters. The diagnosis of Laimaphelenchus species has been commonly based on the presence or absence of a vulval flap and on the shape structure of the tail tip. The species described here has been included in the Laimaphelenchus group without vulval flap, and can be distinguished from morphologically similar species by its tail tip shape structure that has a stalk-like terminus and three diffuse tubercles with 4-6 finger-like protrusions. For the molecular analyses, the mitochondrial DNA region from the cytochrome oxidase subunit
\end{abstract}

\section{M. N. Maleita}

CIEPQPF - Chemical Process Engineering and Forest Products Research Centre, Department of Chemical Engineering, University of Coimbra (UC), Rua Sílvio Lima, Pólo II, Pinhal de Marrocos, P-3030 790 Coimbra, Portugal

C. M. N. Maleita $(\triangle) \cdot$ I. Abrantes

CFE - Centre for Functional Ecology, Department of Life

Sciences, UC, Calçada Martim de Freitas, P-3000 456 Coimbra, Portugal

e-mail: carlamnmaleita@hotmail.com

\section{S. R. Costa}

Mountain Research Center (CIMO), ESA, Polytechnic Institute of Bragança, Campus de Santa Apolónia, P-5300 253 Bragança, Portugal

S. R. Costa

CBMA - Centre of Molecular and Environmental Biology, Department of Biology, University of Minho, Campus de Gualtar, P-4710 057 Braga, Portugal
I (mtCOI), the D2-D3 expansion segments of the large subunit (LSU) and small subunit (SSU) of rRNA gene were amplified and sequenced. Sequences of L. suberensis sp. nov. clustered separately from all Laimaphelenchus spp. with available sequences in Genbank, confirming its identification as a new species. This is the second report of the genus Laimaphelenchus in Portugal, associated with Q. suber: L. heidelbergi and L. suberensis sp. nov.

Keywords Cytochrome oxidase subunit I . Cork oak . Large subunit ribosomal RNA · Molecular analysis . Morphology · Small subunit ribosomal RNA

\section{Introduction}

During a field survey, conducted in 2011, an undescribed species of Laimaphelenchus was found associated with cork oak, Quercus suber, in the Alentejo region of Portugal. The new species is described and illustrated in the present study as L. suberensis sp. nov. Recently, L. heidelbergi, originally described from wood of Pinus radiata growing in Australia, was also reported for the first time in Portugal associated with cork oak (Maleita et al. 2015).

The genus Laimaphelenchus Fuchs, 1937 belongs to the family Aphelenchoididae Skarbilovich, 1947 and comprises non-pathogenic species mostly associated with moss, algae and lichens on conifers and with galleries of bark beetle larvae (Yeates et al. 1993; Hunt 2008). This genus comprises 17 valid species, two of 
which have recently been added, L. belgradiensis Miraeiz et al., 2015 and L. hyrcanus Oro, 2015.

The objectives of this research were to characterise the new Laimaphelenchus species by biometrical and molecular characters; and to analyse the molecular relationship of L. suberensis sp. nov. compared with other Laimaphelenchus spp. with available mitochondrial cytochrome oxidase subunit I (mtCOI), D2-D3 expansion segments of the large subunit (LSU) of rRNA and small subunit (SSU) of rRNA gene sequences. The status of the presence/absence of vulval flap in Laimaphelenchus diagnosis is also discussed and clarified.

\section{Materials and methods}

In 2011, a field survey on cork oak was conducted at two farms located in Montemor-o-Novo, Alentejo region, Portugal: Herdade do Freixo do Meio and Herdade da Gouveia de Baixo. At each farm, two areas were chosen for contrasting tree health: an area with visually healthy cork oaks, and an area with declining cork oaks and/or associated tree mortality. Nematodes were extracted from $10 \mathrm{wood} /$ bark samples per area using the modified Baermann funnel method (Abrantes et al. 1976) and identified as belonging to the genus Laimaphelenchus according to specific morphological characteristics. Nematodes belonging to this genus were handpicked, washed several times with sterilised tap water and transferred to cultures of Botrytis cinerea grown on malt extract agar. Cultures were maintained in a growth chamber at $25{ }^{\circ} \mathrm{C}$ and, every two months, small plugs of agar containing nematodes were transferred to fresh cultures of $B$. cinerea. Four isolates, obtained from bark of two trees of the area with declining cork oaks of Herdade da Gouveia de Baixo (GB), were identified as an undescribed species, Laimaphelenchus suberensis sp.nov. However, only one isolate from each tree (GB1.1 and GB2.1) was studied in detail.

Morphological and morphometrical observations were carried out on males and females of each isolate of $L$. suberensis sp. nov. Females and males were transferred to a drop of water on a plain slide, relaxed by heat and measured immediately. Photographs were taken with a Leitz Dialux 20 bright field light microscope (LM). At least 15 specimens of each sex were examined.

For the preparation of type material (isolate GB1.1), adult males and females were killed by heat, fixed in
TAF (7 mL 37\% formaldehyde, $2 \mathrm{~mL}$ triethanolamine, $91 \mathrm{~mL}$ distilled water), processed by the rapid glycerolethanol method (Hooper 1986) and mounted in pure anhydrous glycerol. Adult males and females were also processed for scanning electron microscope (SEM) studies as described by Abrantes and Santos (1991). The specimens were mounted on stubs, coated with gold (200 $\AA$ ), observed and photographed with a JEOL JSM-35C.

Sequence analyses of the D2-D3 expansion segments of LSU of rRNA and mtCOI were performed for all four isolates, and the SSU rRNA gene was only studied for GB2 isolates, according to Maleita et al. (2015) and Zhao et al. (2008). Laimaphelenchus suberensis sp. nov. sequences were aligned using Muscle (Edgar 2004) with homologues Laimaphelenchus spp. sequences available in GenBank (Maleita et al. 2015).

\section{Results}

\section{Description}

Measurements of Laimaphelenchus suberensis sp. nov. are presented in Table 1.

\section{Females}

Long, slender, ventrally arcuate with curvature more pronounced in posterior region when heat relaxed. Body annules ca. 1.1-1.2 $\mu \mathrm{m}$ wide at mid-body. Lateral field with four incisures, occupying about 17$18 \%$ of the body width, not areolated (Figs. $1 \mathrm{k}$ and $2 \mathrm{e}$ ). Cephalic region rounded, offset by a constriction, wider than the anterior portion of the neck, labial disc not clearly demarcated (Figs. 1a,b and 2c). Head annulated (visible under SEM) with seven annules and six similar labial sectors (Fig. 1b). Oral aperture surrounded by six inner labial papillae and four cephalic papillae. Amphid openings located between first and second annules (Fig. 1b). Stylet delicate, knobs small, stylet cone about $30 \%$ of the length of the stylet. Metacorpus generally oval, 11.5-15.1 $\mu \mathrm{m}$ long by 13.6-10.5 $\mu \mathrm{m}$ wide. Valve plates occupy a central to posterior position $(2.6-4.5 \mu \mathrm{m}$ long by $2.1-3.4 \mu \mathrm{m}$ wide). Excretory pore difficult to discern under light microscopy (Fig. 1a). Pharyngeal glands overlap intestine on dorsal side. Reproductive system outstretched, with one ovary directed anteriorly (monoprodelphic). Ovary with oocytes in a single row. 
Table 1 Morphometrics of females and males of two isolates (GB1.1 and GB2.1) of Laimaphelenchus suberensis sp. nov. ${ }^{\text {a }}$

\begin{tabular}{|c|c|c|c|c|c|c|}
\hline \multirow[t]{2}{*}{ Characteristic } & \multicolumn{4}{|l|}{ GB1.1 } & \multicolumn{2}{|l|}{ GB2.1 } \\
\hline & $\begin{array}{l}\text { Female } \\
\text { holotype }\end{array}$ & $\begin{array}{l}\text { Male } \\
\text { allotype }\end{array}$ & $\begin{array}{l}\text { Female paratypes } \\
(n=15)\end{array}$ & $\begin{array}{l}\text { Male paratypes } \\
(n=15)\end{array}$ & $\begin{array}{l}\text { Female paratypes } \\
(n=15)\end{array}$ & $\begin{array}{l}\text { Male paratypes } \\
(n=15)\end{array}$ \\
\hline \multicolumn{7}{|l|}{ Linear ( $\mu \mathrm{m})$} \\
\hline Body length & 806.7 & 676.7 & $\begin{array}{l}826.1 \pm 75.1 \\
(693.3-940.0)\end{array}$ & $\begin{array}{l}633.4 \pm 43.7 \\
(545.0-710.0)\end{array}$ & $\begin{array}{l}822.7 \pm 63.5 \\
(651.7-906.7)\end{array}$ & $\begin{array}{l}755.1 \pm 67.1 \\
(675.0-850.0)\end{array}$ \\
\hline Greatest body width & 15.8 & 15.3 & $\begin{array}{l}17.4 \pm 1.4 \\
(15.0-20.5)\end{array}$ & $\begin{array}{l}14.6 \pm 0.9 \\
(13.2-16.3)\end{array}$ & $\begin{array}{l}20.1 \pm 2.2 \\
(16.3-23.2)\end{array}$ & $\begin{array}{l}17.1 \pm 1.4 \\
(14.2-20.0)\end{array}$ \\
\hline $\begin{array}{l}\text { Anterior end to posterior end } \\
\text { of pharyngeal glands }\end{array}$ & 165.0 & - & $\begin{array}{l}163.6 \pm 21.4 \\
(109.3-182.9)\end{array}$ & - & $\begin{array}{l}150.6 \pm 17.4 \\
(127.1-185.7)\end{array}$ & - \\
\hline Lip region height & 2.9 & 2.6 & $\begin{array}{l}2.8 \pm 0.3 \\
(2.4-3.2)\end{array}$ & $\begin{array}{l}2.7 \pm 0.3 \\
(2.4-3.2)\end{array}$ & $\begin{array}{l}3.2 \pm 0.2 \\
(2.9-3.4)\end{array}$ & $\begin{array}{l}2.96 \pm 0.2 \\
(2.6-3.4)\end{array}$ \\
\hline Lip region width & 5.3 & 5.8 & $\begin{array}{l}6.0 \pm 0.2 \\
(5.5-6.3)\end{array}$ & $\begin{array}{l}5.6 \pm 0.2 \\
(5.5-6.1)\end{array}$ & $\begin{array}{l}6.1 \pm 0.3 \\
(5.8-6.6)\end{array}$ & $\begin{array}{l}5.95 \pm 0.4 \\
(5.3-6.8)\end{array}$ \\
\hline Stylet length & 10.53 & 11.1 & $\begin{array}{l}11.6 \pm 0.4 \\
(10.8-12.1)\end{array}$ & $\begin{array}{l}11.4 \pm 0.5 \\
(10.5-12.1)\end{array}$ & $\begin{array}{l}11.4 \pm 0.4 \\
(10.5-12.1)\end{array}$ & $\begin{array}{l}11.1 \pm 0.5 \\
(10.0-11.8)\end{array}$ \\
\hline Anterior end to metacorporal valves & 53.2 & 50.8 & $\begin{array}{l}56.3 \pm 2.5 \\
(52.6-61.1)\end{array}$ & $\begin{array}{l}55.4 \pm 2.4 \\
(50.0-58.2)\end{array}$ & $\begin{array}{l}53.8 \pm 4.5 \\
(47.4-66.3)\end{array}$ & $\begin{array}{l}56.5 \pm 7.6 \\
(47.6-74.7)\end{array}$ \\
\hline Tail length & 35.3 & 33.7 & $\begin{array}{l}37.1 \pm 3.2 \\
(32.1-43.7)\end{array}$ & $\begin{array}{l}35.4 \pm 3.1 \\
(30.3-41.6)\end{array}$ & $\begin{array}{l}37.6 \pm 3.8 \\
(29.7-43.4)\end{array}$ & $\begin{array}{l}37.6 \pm 5.1 \\
(31.1-48.4)\end{array}$ \\
\hline Body width at anus & 10.5 & 12.1 & $\begin{array}{l}10.5 \pm 0.5 \\
(9.2-11.3)\end{array}$ & $\begin{array}{l}12.7 \pm 0.6 \\
(11.6-14.2)\end{array}$ & $\begin{array}{l}11.2 \pm 0.9 \\
(9.2-12.1)\end{array}$ & $\begin{array}{l}14.1 \pm 1.2 \\
(12.6-16.8)\end{array}$ \\
\hline Anterior end to vulva & 703.8 & - & $\begin{array}{l}721.3 \pm 75.3 \\
(600.5-846.4)\end{array}$ & - & $\begin{array}{l}710.3 \pm 51.8 \\
(568.8-779.5)\end{array}$ & - \\
\hline Vulva width & 15.3 & - & $\begin{array}{l}17.2 \pm 0.9 \\
(15.3-18.4)\end{array}$ & - & $\begin{array}{l}19.1 \pm 2.13 \\
(15.0-21.8)\end{array}$ & - \\
\hline Spicule length & - & 17.1 & - & $\begin{array}{l}16.8 \pm 1.8 \\
(13.7-19.7)\end{array}$ & - & $\begin{array}{l}16.9 \pm 1.5 \\
(12.4-19.5)\end{array}$ \\
\hline \multicolumn{7}{|l|}{ Ratio } \\
\hline $\mathrm{a}=$ Body length $/$ body width & 51.1 & 44.3 & $\begin{array}{l}47.5 \pm 2.9 \\
(42.9-52.5)\end{array}$ & $\begin{array}{l}43.3 \pm 2.0 \\
(40.7-47.4)\end{array}$ & $\begin{array}{l}41.1 \pm 3.2 \\
(35.9-46.3)\end{array}$ & $\begin{array}{l}44.4 \pm 4.6 \\
(38.6-56.7)\end{array}$ \\
\hline b' = Body length/pharyngeal glands & 4.9 & - & $\begin{array}{l}4.9 \pm 0.9 \\
(4.3-7.4)\end{array}$ & - & $\begin{array}{l}5.5 \pm 0.7 \\
(4.3-7.0)\end{array}$ & - \\
\hline $\mathrm{c}=$ Body length/tail length & 22.9 & 20.1 & $\begin{array}{l}22.4 \pm 2.6 \\
(16.8-27.1)\end{array}$ & $\begin{array}{l}18.0 \pm 1.3 \\
(15.6-20.3)\end{array}$ & $\begin{array}{l}22.0 \pm 1.5 \\
(19.5-24.6)\end{array}$ & $\begin{array}{l}20.3 \pm 2.3 \\
(16.3-24.2)\end{array}$ \\
\hline $\mathrm{c}^{\prime}=$ tail/body width at anus & 3.4 & 2.8 & $\begin{array}{l}3.5 \pm 0.3 \\
(3.1-4.0)\end{array}$ & $\begin{array}{l}2.8 \pm 0.2 \\
(2.4-3.0)\end{array}$ & $\begin{array}{l}3.4 \pm 0.3 \\
(2.8-3.9)\end{array}$ & $\begin{array}{l}2.7 \pm 0.3 \\
(2.3-3.2)\end{array}$ \\
\hline
\end{tabular}

${ }^{\text {a }}$ Values are mean \pm standard deviation (range)

Vagina slooping slightly anteriorly, not sclerotised, surrounded by a cuticularised tube and by welldeveloped muscles; sclerotised pieces surrounding the tube were not observed (Figs. 1i,j and 2d). Vulva without flap (Figs. 1i,j and 2d). Tail conoid, ventrally curved, with a single stalk-like terminus (visible by LM) and three diffuse tubercles with 4-6 finger-like protrusions (visible only by SEM) (Figs. 1d-f and $2 \mathrm{f}$ ).

\section{Males}

Morphology similar to that of female, however more curved, especially in tail region, when heat relaxed. Reproduction system monarchic (one testis), reflexed, with developing germ cells arranged in a single column near the anterior end of the testis (Fig. 1c). At mid-part germ cells form a double 

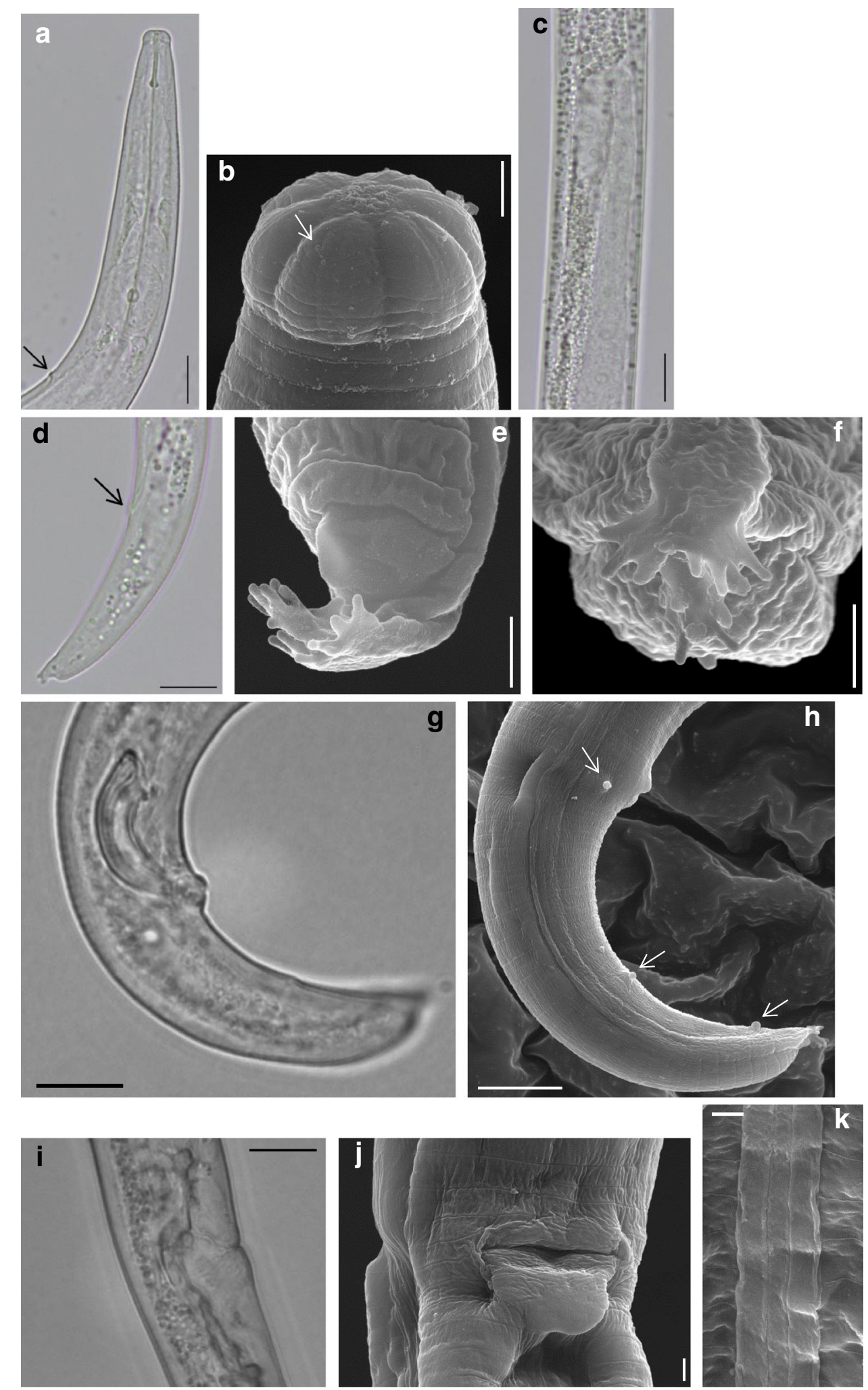
Fig. 1 Light (a, c, d, $\mathbf{g}$ and $\mathbf{i})$ and scanning electron (b, e-f, $\mathbf{h}, \mathbf{j}$ and $\mathbf{k}$ ) microscope photographs of Laimaphelenchus suberensis sp. nov.: a female anterior end showing the excretory pore (arrow); b female head showing the amphids openings (arrow); c male reproduction system monarchic (one testis), reflexed; d female posterior end showing the anus (arrow); e-f female tail tip with fringered tubercles; $\mathbf{g}$-h male tail showing the papillae (arrows); $\mathbf{i}-\mathbf{j}$ female vulval region; k lateral field. Scale bars a, c-d, g, $i=10 \mu \mathrm{m}$, $\mathrm{h}=5 \mu \mathrm{m}, \mathrm{b}, \mathrm{e}-\mathrm{f}, \mathrm{j}-\mathrm{k}=1 \mu \mathrm{m}$

column. Spicules paired, 12.4-19.4 $\mu \mathrm{m}$ long (measured along the central arc from capitulum to tip), with a rounded capitulum, not prominent; a short rostrum and a rounded tip (Figs. $1 \mathrm{~g}$ and $2 \mathrm{~g}$ ). Gubernaculum absent. Three pairs of papillae were observed: first pair adanal subventral at level or just anterior to cloaca; second pair post-cloacal subventral, about $60 \%$ distance between cloaca and tail tip; and a third pair subventral near tail tip (Fig. 1h). Tail conoid and morphologically similar to that of females, but more curved ventrally (Fig. $2 \mathrm{~g}$ ).

Holotype Female in Nematode Collection of the Nematology Laboratory of the Department of Life Sciences, University of Coimbra.

Allotype Male in Nematode Collection of the Nematology Laboratory of the Department of Life Sciences, University of Coimbra.

Paratypes Three females and three males were deposited in WaNeCo-Wageningen Nematode Collection, Wageningen University and Research Centre.
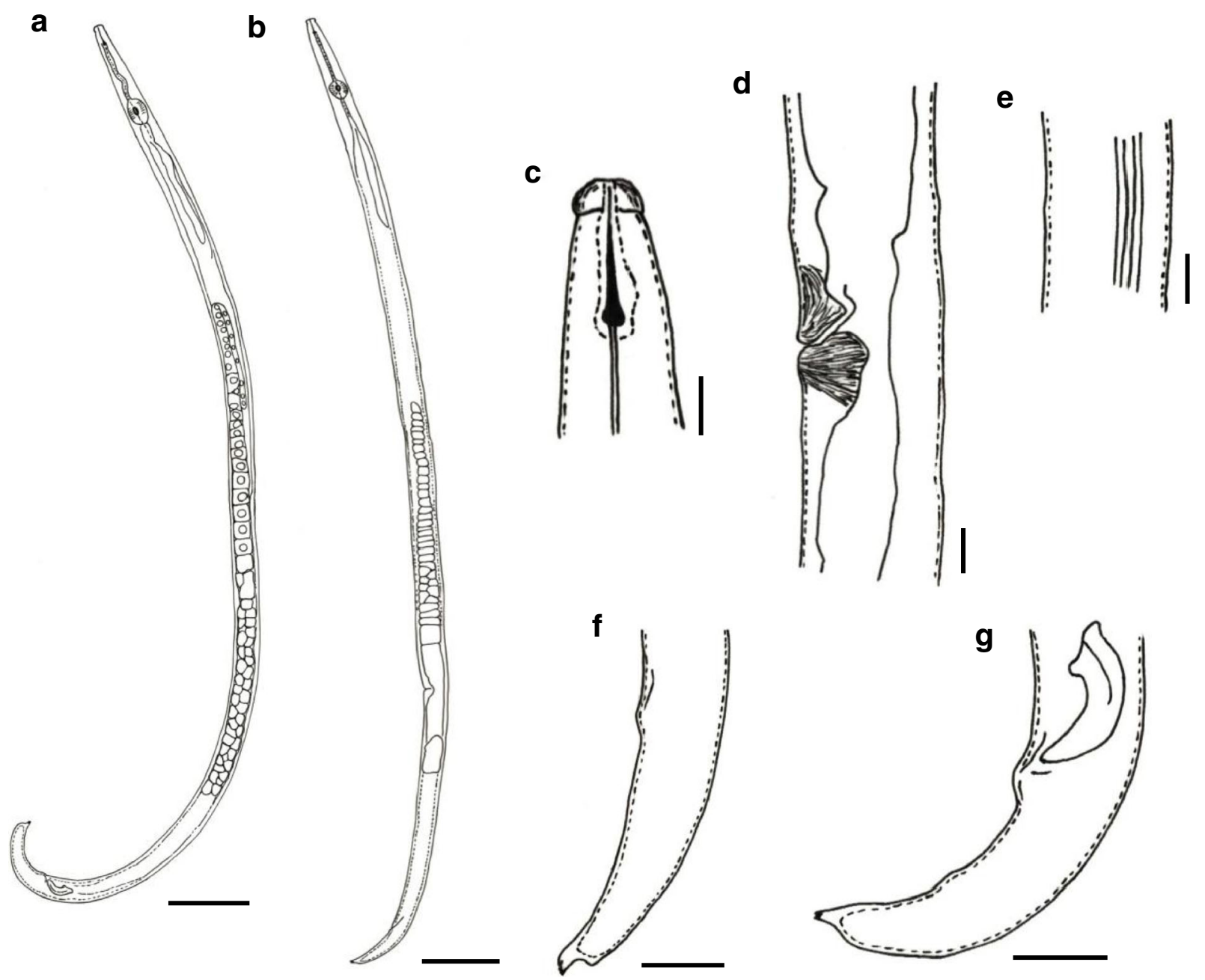

Fig. 2 Laimaphelenchus suberensis sp. nov.: a entire body of male; $\mathbf{b}$ entire body of female; $\mathbf{c}$ anterior region; $\mathbf{d}$ vulval region; $\mathbf{e}$ lateral field; f female tail region; $\mathrm{g}$ male tail region with spicules. Scale bars $\mathrm{a}, \mathrm{b}=50 \mu \mathrm{m}, \mathrm{c}-\mathrm{g}=5 \mu \mathrm{m}$ 
Type locality and habitat The specimens were obtained from bark samples of two declining trees (branches) of cork oak, Quercus suber, in Herdade da Gouveia de Baixo, Montemor-o-Novo Municipality, Alentejo region, Portugal. Laimaphelenchus suberensis sp. nov. seems to be associated with lichens, algae or mosses growing on the bark of cork oak trees.

\section{Diagnosis}

Laimaphelenchus suberensis sp. nov. differs from all Laimaphelenchus species by the tail tip shape structure which exhibits a single stalk-like terminus and three diffuse tubercles with 4-6 finger-like protrusions in both sexes. Additionally, this species is characterised by the cephalic region offset by a constriction; cephalic region with six similar labial sectors and lack of a demarcated labial disc; lateral field with four incisures; vulva without flap; and three pairs of caudal subventral papillae, one at level or just anterior to cloaca, one at about $60 \%$ of the distance between cloaca and tail tip, and one on the tail tip just before the tubercle.

\section{Morphological comparisons}

Laimaphelenchus suberensis sp. nov. belongs to the species group without a vulval flap, and therefore it is compared with species without this character: L. australis Zhao et al., 2006a; L. heidelbergi Zhao et al., 2007; L. pannocaudus Massey, 1966; L. patulus Swart, 1997; L. phloesini Massey, 1974; and L. pini Baujard, 1981 (Table 2). The new species forms a group with L. phloesini, L. pannocaudus and L. pini by having a tail ending in a single stalk with 3-4 fringed tubercles, four incisures in the lateral field and three pairs of caudal papillae. In comparison, $L$. suberensis sp. nov. is larger than L. phloesini $(0.43-0.51 \mathrm{~mm})$ and L. pini $(0.35-$ $0.47 \mathrm{~mm}$ ) and the tail tip differs in having three diffuse tubercles each with 4-6 finger-like protrusions. Laimaphelenchus pannocaudus appears very similar to L. suberensis, but differs by a longer body (0.7$1.06 \mathrm{~mm})$, lateral field with two median incisures less distinct, greater ratio $a$ (46-62.5), and a tail with four fringed tubercles. However, some of the characters such as tail shape and number of caudal papillae are only visible in detail with SEM. Laimaphelenchus suberensis sp. nov. can be easily differentiated from L. patulus, $L$. australis and $L$. heidelbergi by the combination of tail shape and number of caudal papillae. Laimaphelenchus australis has 3-4 pedunculated tubercles, with 4-6 finger-like protrusions; whereas L. patulus has a tail ending with four diffuse tubercles with fringed-like protrusions at its tip and two or three pairs of caudal papillae. In addition, $L$. heidelbergi exhibits a conoid posterior end with a single tubercle covered by several knob-like protrusions and two pairs of subventral caudal papillae, and a single ventral papilla near tail tip (Table 2).

\section{Etymology}

The specific epithet refers to the specific epithet of the host, Quercus suber, from which this new species was recovered.

Molecular relationships

From the 17 valid Laimaphelenchus species only eight were already characterised molecularly using the D2-D3 expansion segments of LSU: L. hyrcanus, L. belgradiensis, L. persicus, L. penardi, L. deconincki, $L$. preissii, L. australis and L. heidelbergi. Laimaphelenchus suberensis sp. nov. (GB1 and GB2) occurred in a $92 \%$ supported clade with Laimaphelenchus spp. having a vulval flap (Fig. 3a). According to the molecular analysis, this species is most similar to L. persicus, L. hyrcanus and L. belgradiensis, with a sequence divergence of $24 \%$. The differences include 149 (L. persicus) to 153 (L. hyrcanus and L. belgadiensis) nucleotide changes, insertions and deletions in 668 bp. Laimaphelenchus suberensis sp. nov. displayed sequence divergences ranging from 32 to $50 \%$ when compared with species without a vulval flap (L. australis and L. heidelberdi) (data not shown). Laimaphelenchus hyrcanus and L. belgradiensis, described recently, formed a well-supported clade (100\%) with the exclusion of L. persicus (Fig. 3a). These Laimaphelenchus species differ in only three nucleotide changes at positions 95, 141 and 312 (data not shown).

Although the number of species included differs, phylogenetic trees obtained from Maximum Likelihood method analysis of sequences of D2-D3 expansion segments of LSU and SSU rRNA gene were similar, showed the same relations between Laimaphelenchus species and revealed two distinct groups of species: one with species with a vulval flap and the other without (Figs 3a,b). However, in the mtCOI phylogram species with a vulval flap (L. preissii and L. belgradiensis) are associated with 


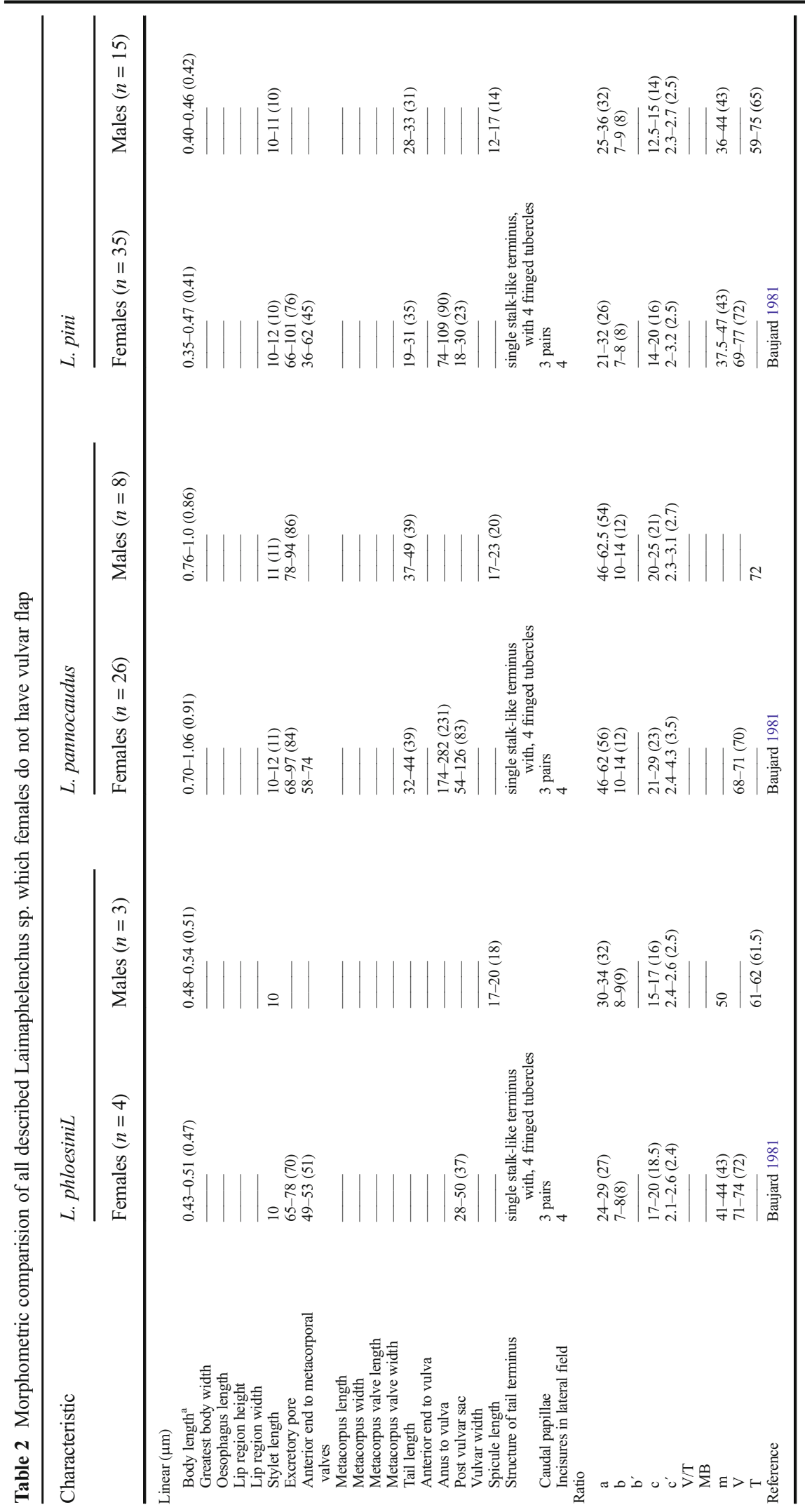




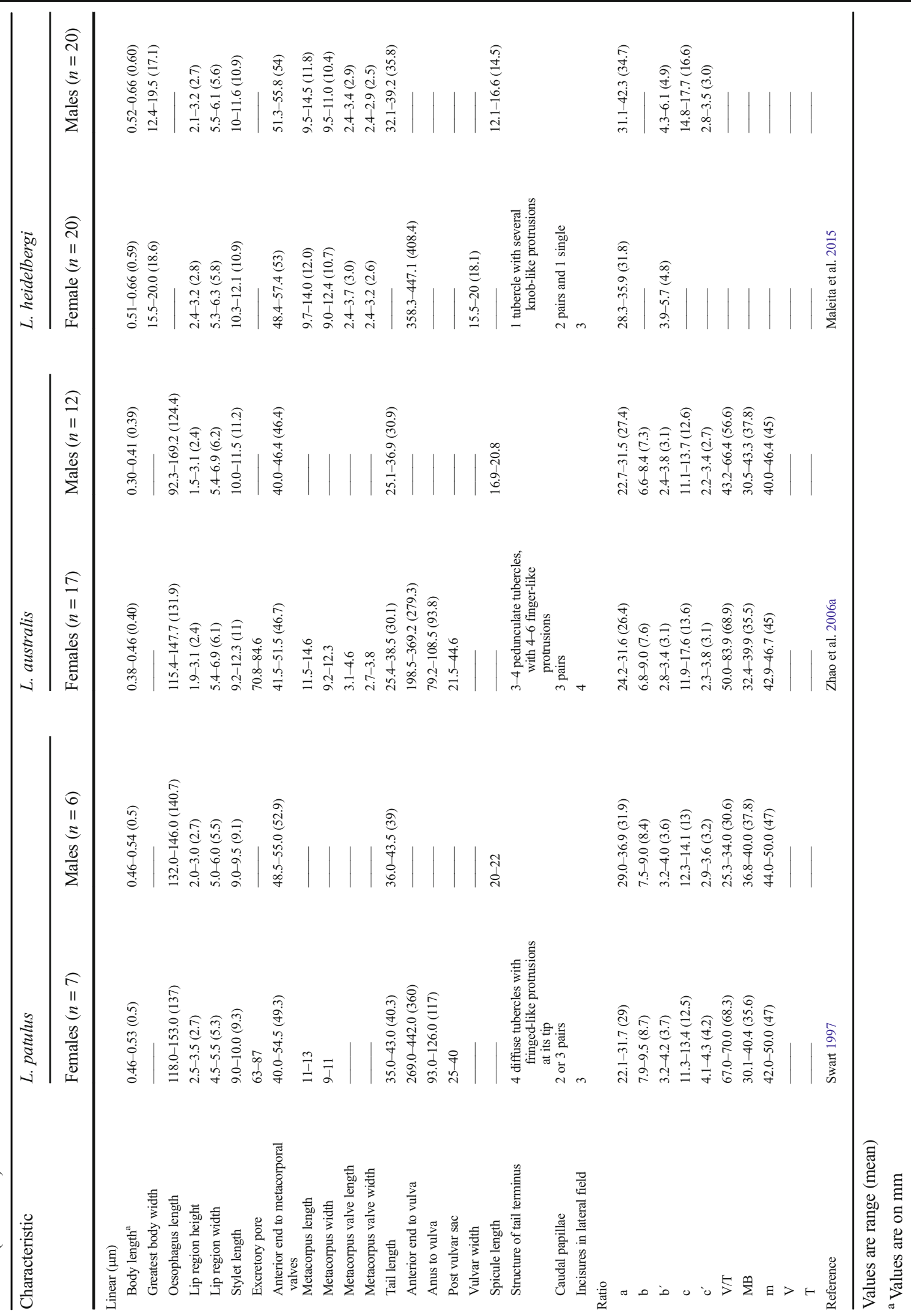


species without a vulval flap (L. suberensis sp. nov. and L. heidelbergi) (Fig. 3c). There are only three mtCOI sequences of Laimaphelenchus spp. available on GenBank and the relationships between these species differ when compared with SSU and LSU phylogenetic trees: L. heidelbergi formed a well-supported clade with L. belgradiensis, with $100 \%$ bootstrap (Fig. 3c). mtCOI sequences of GB isolates were compared and GB1 had 99.8\% homology with GB2 sequences with only two differences in alignment (data not shown). Laimaphelenchus suberensis sp. nov. was a sister taxon with $L$. preissii, but with lower bootstrap (50\%) and clustered separately from the other two species included for comparison (Fig. 3c). When compared with L. preissii, L. suberensis sp. nov. differed by 10.9 to $11.2 \%$ (81-83 nucleotide changes) (data not shown).

Our molecular analyses agree with phylograms obtained by Zhao et al. (2008), Asghari and Eskandari (2014), Maleita et al. (2015), Miraeiz et al. (2015) and Oro (2015).

The SSU sequences of GB2 isolates were deposited in the Genbank as KX580736 and KX580737; and the LSU and mtCOI sequences as KX580738, KX580739, KX580740 and KX580741 for LSU and KX580742, KX580743, KX580744 and KX580745 for mtCOI.

\section{Discussion}

From the 17 valid species of the genus Laimaphelenchus, L. belgradiensis, L. deconinki, L. heidelbergi, L. pannocaudus, L. penardi and L. pini have been recorded in Europe (Elmiligy and Geraert 1971; Baujard 1981; Maleita et al. 2015; Oro 2015). Laimaphelenchus heidelbergi, originally described from wood of Pinus radiata, Australia, was reported recently in Portugal associated with cork oak, a new habitat record for this species (Zhao et al. 2007; Maleita et al. 2015). To our knowledge, this is the second report of the genus Laimaphelenchus in Portugal, associated with Quercus suber.

Nematodes were extracted separately from wood and bark of cork oak trees and according to the results, L. suberensis sp. nov. is not associated with wood of the trees. These nematodes probably feed on lichens, algae or mosses growing on the bark of cork oak. No beetle activities were observed on the sampled trees. Nematode isolates were successfully reared on $B$. cinerea in the laboratory, which indicated that this new Laimaphelenchus species also can feed and develop on fungi.

Hunt based the diagnosis of the genus Laimaphelenchus on shape and structure of the tail tip, bearing four pedunculate tubercles with fringed margins (Hunt 1993). In turn, Zhao et al. (2007) showed that the tail terminus, which can only observed in sufficient detail with SEM, varies between species, and is an important character for Laimaphelenchus diagnosis. Some species are reported to have a single terminus (tubercle) on the tail with small projections, whilst other species have three or four fringed tubercles or other forms. Laimaphelenchus suberensis sp. nov. has a single stalk-like terminus, visible by LM, and three diffuse tubercles with 4-6 finger-like protrusions, visible by SEM. Although, the tail structure is obvious by using SEM, this new species can be confused with other Laimaphelenchus species by using only LM. Molecularly, L. suberensis sp. nov. was a sister taxon with $L$. preissii; however they differs in several morphological characters: body length (545-940 $\mu \mathrm{m}$ vs 1000 $1386 \mu \mathrm{m}$, respectively); body annules width $(1.1 \mu \mathrm{m}$ vs $1.5 \mu \mathrm{m})$; stylet length (10-12 $\mu \mathrm{m}$ vs $11-17 \mu \mathrm{m})$; vulval flap (absence vs presence, although in the original description the figure was not clear); structure of tail terminus (three diffuse tubercles with 4-6 finger-like protrusions vs one broad tubercle with about 10 projections); test structure (reflexed vs not reflexed); spicules structure (not prominent capitulum vs prominent); and number of caudal papillae (three pairs vs two pairs) (Zhao et al. 2006b). Laimaphelenchus heidelbergi appears as the most divergent species, which is supported by the typical tail shape: posterior end conoid with a single tubercle, visible with LM, covered by 20-30 min finger-like appendages, only observed in detail with SEM (Maleita et al. 2015).

Laimaphelenchus species can be divided in two groups taking into account the presence/absence of a distinct vulval flap that is easily observed using LM (Zhao et al. 2007). Several cuticular appendages have being found associated with vulva, however different terms were used for the same structure and the same terms applied to different structures, which generates confusion when images are not available. Carta et al. (2009, p. 194) defined the concept of "vulval flap" as a "mild-to-extreme modification of the anterior vulval lip that show up as overhanging extensions of cuticle oriented parallel and anterior to the vulval slit". According to the Laimaphelenchus species descriptions, 

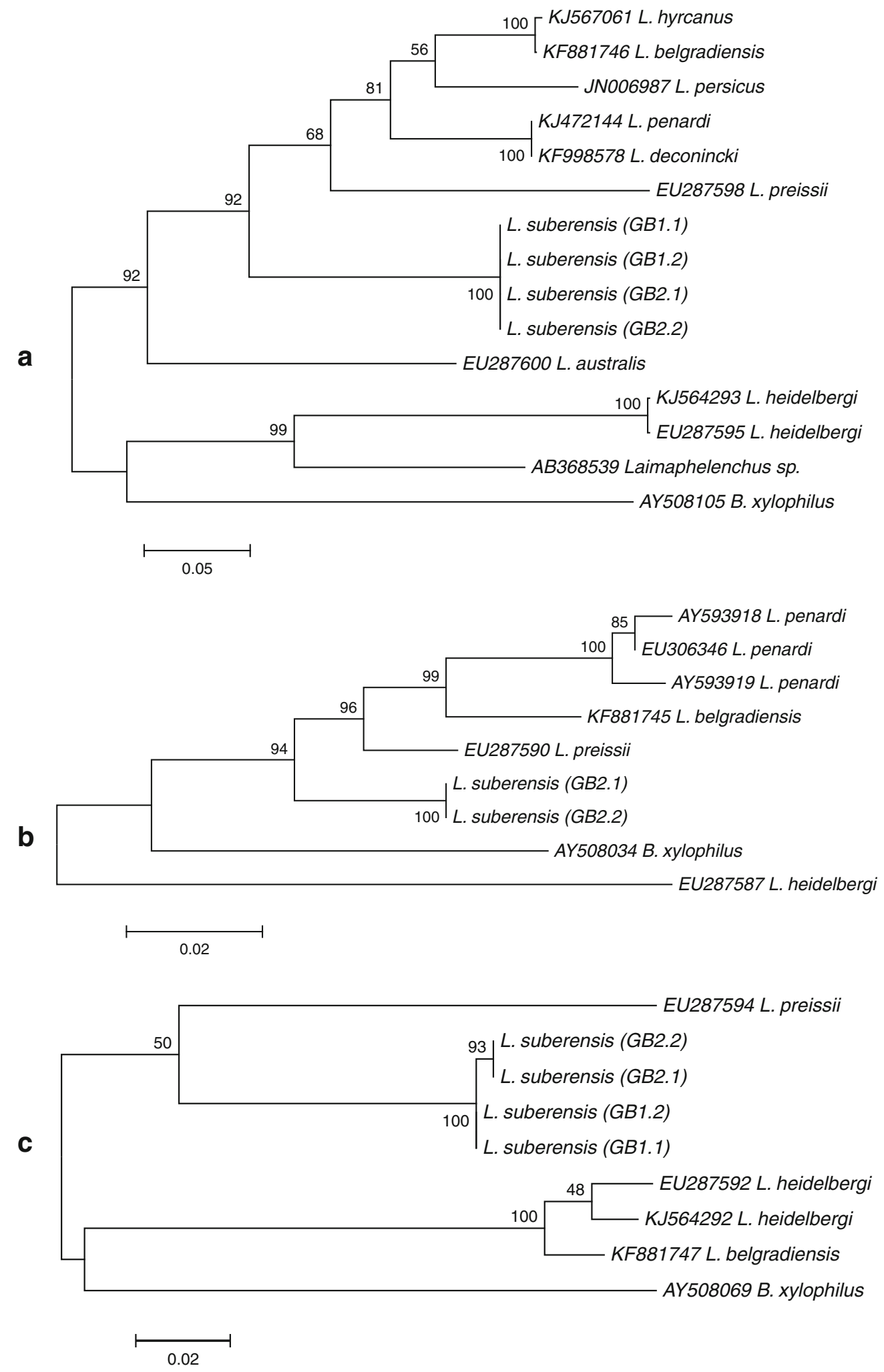
Fig. 3 Molecular relationships of Laimaphelenchus based on the D2-D3 expansion segments of large subunit of rRNA (a), small subunit of rRNA gene (b) and mitochondrial cytochrome oxidase subunit I (c) sequences and inferred by using the Maximum Likelihood method based in the Jukes-Cantor model. All positions containing gaps and missing data were eliminated. Bursaphelenchus xylophilus was included as an out-group

L. australis Zhao et al., 2006a; L. heidelbergi Zhao et al., 2007; L. pannocaudus Massey, 1966; L. patulus Swart, 1997; and L. pini Baujard, 1981 clearly not showed a vulval flap (Baujard 1981; Swart 1997; Zhao et al. 2006a, 2007). Only L. phloesini, regarded as not showing a vulval flap (Zhao et al. 2007), revealed variations in the vagina morphology (Baujard 1981). A variable direction of the vagina can be observed and, in some cases, the posterior lip apparently displayed an extension of cuticle oriented anteriorly, similar with a vulval flap but with inverted orientation (Baujard 1981; Carta et al. 2009).

Although, vulval flaps are considered unreliable for species identification of Haemonchus and Ashworthius genera (Carta et al. 2009), this character emerges as a valid character to differentiate Laimaphelenchus species limiting the number of comparisons between species. Differentiation of the species based on vulval flap (presence/absence) is sustained by molecular evidences, particularly by the D2-D3 expansion segments of LSU of rRNA and the SSU rRNA gene.

Nematodes of the genus Laimaphelenchus are a good example of the difficulties associated with taxonomy based only on LM. SEM observations are needed mainly to clearly characterise and describe the shape and structure of the tail tip. Thus, additional molecular methodologies should also be used. D2-D3 expansion segments of LSU, SSU rRNA gene, and mtCOI sequences confirmed that $L$. suberensis sp. nov. fits in the genus Laimaphelenchus and was distinct from all Laimaphelenchus species with available sequences on database. Although the molecular proximity of L. suberensis sp. nov. with $L$. preissii detected in the phylogenetic analysis of mtCOI sequences, these two species can easily distinguished by morphological characterisation.

mtCOI was proposed as a molecular marker for DNA barcoding because mtDNA evolves faster than other DNA regions, such as rRNA genes, creating sufficient nucleotide variation capable of discriminating between nematode species (Ahmed et al. 2016). Nevertheless, this region does not differentiate species with vulval flap from species without. Considering that the presence/ absence of vulval flap on females is a useful morphological character for species identification, the rRNA genes are more reliable than the mtCOI gene. Furthermore, there are more sequences from rRNA genes available in databases and a combination of the LSU and SSU genes can improve the species detection/ discrimination (Porazinska et al. 2009).

Acknowledgments This research was supported by CFE, CIEPQPF and FEDER funds through the 'Programa Operacional Factores de Competitividade - COMPETE' and by national funds through FCT-Fundação para a Ciência e a Tecnologia under the projects UID/BIA/04004/2013, PEst-C/EQB/UI0102/2013 and FCOMP-01-0124-008937 (Ref. PTDC/BIA-BEC/102834/2008) and by Instituto do Ambiente, Tecnologia e Vida (IATV). Carla Maleita (SFRH/BPD/85736/2012) and Sofia Costa (SFRH/BPD/ 102438/2014) were financed by MEC National funding and The European Social Fund through POCH (Programa Operacional Capital Humano).

\section{Compliance with ethical standards}

Conflict of interest The authors certify that do not have any actual or potential conflict of interest, the study described is original, has not been published previously, and is not under consideration for publication elsewhere. All authors have reviewed the manuscript and approved the final version of manuscript before submission.

Research involving human participants and/or animals No specific permits were required for the described studies. Permission for sampling the cork oak farms was granted by the landowner.

Informed consent The authors certify that the work carried out in this research followed the principles of ethical and professional conduct.

\section{References}

Abrantes, I. M. de O., \& Santos, M. S. N. de A. (1991). Meloidogyne lusitanica n. sp. (Nematoda: Meloidogynidae), a root-knot nematodes parasitizing olive tree (Olea europaea L.) Journal of Nematology, 23, 210-224.

Abrantes, I. M. de O., de Morais, M. M. N., Paiva, I. M. P. de F. R., \& Santos, M. S. N. de A. (1976). Análise nematológica de solos e plantas. Ciência Biológica (Portugal), 1, 139-155.

Ahmed, M., Sapp, M., Prior, T., Karssen, G., \& Back, M. A. (2016). Technological advancements and their importance for nematode identification. The Soil, 2016, 257-270.

Asghari, R., \& Eskandari, A. (2014). Morphological and molecular characterization of Laimaphelenchus deconincki 
(Nematoda: Aphelenchoididae) based on specimens from Iran. Biologia, 69, 1172-1178.

Baujard, P. (1981). Revue taxonomic du genre Laimaphelenchus Fuchs, 1937 et description de Laimaphelenchus pini n. sp. Revue de Nématologie, 4, 75-92.

Carta, L. K., Handoo, Z. A., Hoberg, E. P., Erbe, E. F., \& Wergin, W. P. (2009). Evaluation of some vulval appendages in nematode taxonomy. Comparative Parasitology, 76, 191209.

Edgar, R. C. (2004). MUSCLE: Multiple sequence alignment with high accuracy and high throughput. Nucleic Acids Research, 32, 1792-1797.

Elmiligy, I., \& Geraert, E. (1971). Laimaphelenchus deconincki n. sp. (Nematoda: Tylenchida). Biologisch Jaarboek, 39, 145149.

Hooper, D. J. (1986). Handling, fixing, staining and mounting nematodes. In J. F. Southey (Ed.), Laboratory methods for work with plant and soil nematodes (pp. 59-80). London: Ministry of Agriculture, Fisheries and Food.

Hunt, D. J. (1993). Aphelenchida, Longidoridae and Trichodoridae: Their systematics and bionomics (pp. 1162). UK: CAB International Wallingford.

Hunt, D. J. (2008). A checklist of the Aphelenchoidea (Nematoda: Tylenchina). Journal of Nematode Morphology and Systematics, 10, 99-135.

Maleita, C., Costa, S. R., \& Abrantes, I. (2015). First report of Laimaphelenchus heidelbergi (Nematoda: Aphelenchoididae) in Europe. Forest Pathology, 45, 76-81.

Massey, C. L. (1966). The nematode parasites and associates of Dendroctonus adjunctus (Coleoptera: Scolytidae) in New Mexico. Annals of the Entomological Society of America, 59, 424-440.

Massey, C. L. (1974). Biology and taxonomy of nematode parasites and associates of bark beetles in the United States. Washington, D.C.: US Department of Agriculture.

Miraeiz, E., Heydari, R., Maafi, Z. T., \& Bert, W. (2015). Laimaphelenchus hyrcanus $\mathrm{n}$. sp. (Nematoda:
Aphelenchoididae), a new species from northern Iran. Zootaxa, 4, 591-600.

Oro, V. (2015). Description of Laimaphelenchus belgradiensis sp. nov. (Nematoda: Aphelenchoididae) and its phylogenetic and systematic position within Aphelenchoidoidea. European Journal of Plant Pathology, 142, 13-23.

Porazinska, D. L., Giblin-Davis, R. M., Faller, L., Farmerie, W., Kanzaki, N., Morris, K., Powers, T. O., Tucker, A. E., Sung, W., \& Thomas, W. K. (2009). Evaluating high-throughput sequencing as a method for metagenomic analysis of nematode diversity. Molecular Ecology Resources, 9, 1439-1450.

Swart, A. (1997). Description of Laimaphelenchus patulus sp. n. (Nematoda: Aphelenchoididae) from Pinus pinaster Ait. in South Africa. African Plant Protection, 3, 23-28.

Yeates, G. W., Bongers, T., Goede, R. G. M. de, Freckman, D. W., \& Georgieva, S. S. (1993). Feeding habits in soil nematode families and genera - An outline for soil ecologists. Journal of Nematology, 25, 315-331.

Zhao, Z. Q., Davies, K. A., Riley, I. T., \& Nobbs, J. M. (2006a). Laimaphelenchus australis sp. nov. (Nematoda: Aphelenchina) from exotic pines, Pinus radiata and P. pinaster, in Australia. Zootaxa, 1248, 35-44.

Zhao, Z. Q., Davies, K. A., Riley, I. T., \& Nobbs, J. M. (2006b). Laimaphelenchus preissii sp. nov. (Nematoda: Aphelenchina) from native pine Callitris preissii in South Australia. Transactions of the Royal Society of South Australia, 130, 10-16.

Zhao, Z. Q., Davies, K. A., Riley, I. T., \& Nobbs, J. M. (2007). Laimaphelenchus heidelbergi sp. nov. (Nematoda: Aphelenchina) from Victoria, Australia, and emendment of the diagnosis of the genus. Transactions of the Royal Society of South Australia, 132, 182-191.

Zhao, Z., Ye, W., Giblin-Davis, R. M., Li, D., Thomas, W. K., Davies, K. A., \& Riley, I. T. (2008). Morphological and molecular analysis of six aphelenchoidoids from Australian conifers and their relationship to Bursaphelenchus (Fuchs, 1937). Nematology, 10, 663-678. 